\title{
Model-Based Assessment of Aspen Responses to Elk Herbivory in Rocky Mountain National Park, USA
}

\author{
PETER J. WEISBERG* \\ Mountain Forest Ecology Group \\ Department of Forest Sciences \\ Swiss Federal Institute of Technology \\ ETH-Zentrum HG F21.5, CH-8092 \\ Zurich, Switzerland
}

\section{MICHAEL B. COUGHENOUR}

Natural Resource Ecology Laboratory

Colorado State University

Fort Collins, Collins, 80523-1499, USA

ABSTRACT / In Rocky Mountain National Park (RMNP), aspen (Populus tremuloides Michx.) has been observed to be declining on elk (Cervus elaphus nelsoni) winter range for many decades. To support elk management decisions, the SAVANNA ecosystem model was adapted to explore interactions between elk herbivory and aspen dynamics. The simulated probability of successful vegetative regeneration for senescent aspen stands declines sharply when elk densities reach levels of
3-5 elk/ $/ \mathrm{km}^{2}$, depending on model assumptions for the seasonal duration of elk foraging activities. For aspen stands with a substantial component of younger trees, the simulated regeneration probability declines more continuously with increasing elk density, dropping below 50\% from densities at 8-14 elk/ $/ \mathrm{km}^{2}$. At the landscape scale, simulated aspen regeneration probability under a scenario of extensive seasonal use was little affected by elk population level, when this level was above 300-600 elk (25\%-50\% current population) over the ca. $107 \mathrm{~km}^{2}$ winter range. This was because elk distribution was highly aggregated, so that a high density of elk occupied certain areas, even at low population levels overall. At approximately current elk population levels (1000-1200 elk), only $35 \%-45 \%$ of senescent aspen stands are simulated as having at least a $90 \%$ probability of regeneration, nearly all of them located on the periphery of the winter range. Successful management for aspen persistence on core winter range will likely require some combination of elk population reduction, management of elk distribution, and fencing to protect aspen suckers from elk browsing.
Ungulate species, both wild and domestic, can profoundly influence the vegetation for which they depend as a food base (Milchunas and others 1989, Hobbs 1996). Elk (Cervus elaphus nelsoni) have been observed to exert pronounced effects on woody vegetation throughout the western United States. For example, intensive herbivory by elk has suppressed willow (Salix spp.) height and leaf biomass in Yellowstone National Park (Singer and others 1994, Kay 1997b), Rocky Mountain National Park (Singer and others 1998) and interior Alaska (Wolff 1978). Although elk are primarily grazers, they require substantial browse (i.e., leaf and twig growth of woody plants) in the winter to maintain adequate levels of protein (Hobbs and others

KEY WORDS: Herbivory; National park management; Simulation models; Ungulate population management; Populus tremuloides; Cervus elaphus; Plant-animal interactions

Published online September 4, 2003.

*Author to whom correspondence should be addressed at current address: Department of Environmental and Resource Sciences, University of Nevada, Reno, 1000 Valley Road, MS 186, Reno, NV 89512, USA, email: pweisberg@cabnr.unr.edu
1981). In Rocky Mountain National Park (RMNP), as much as $44 \%$ of the winter diet has been observed to be browse (Hobbs and others 1981).

A favored browse species of elk, quaking aspen (Populus tremuloides Michx.) may constitute greater than $7 \%$ of the winter diet in RMNP (Hobbs and others 1981). Elk browse aspen leaves and twigs, and strip aspen bark. The effect of bark-stripping on aspen mortality is unknown, although it may create inoculation sites for pathogens that eventually lead to aspen mortality (Hinds 1985, Hart and Hart 2001). The effect of browsing young aspen suckers is more apparent. Suckers may eventually die after being browsed for multiple years, resulting in critical losses of root reserves for the parent tree (Schier 1975). Suckers that are able to persist despite high levels of browsing may develop a shrubby growth form as a result of repeated loss of the apical meristem (Olmsted 1977, 1997).

In Rocky Mountain National Park, aspen has been observed to be declining, in the low-elevation valleys and dry parks constituting core elk winter range, for many decades (Dixon 1939 from Gysel 1960, Olmsted 1977, Stevens 1979, Hess 1993, Baker and others 1997). 
Elk effects upon aspen in RMNP have been a contentious issue and have been repeatedly studied (Olmsted 1977, Baker and others 1997, Suzuki and others 1999). Aspen regeneration on core elk winter range has been episodic and associated with periods of low elk population (Baker and others 1997). Elk populations have fluctuated markedly over the past 150 years. Intensive hunting virtually extirpated elk from the park from about 1875 to 1913 , when 49 elk were transplanted to the ca. $107 \mathrm{~km}^{2}$ winter range (Hess 1993). After population levels increased rapidly to over 1000 elk by the late 1930s, elk populations in RMNP were controlled by shooting from 1943 through 1962 (Olmsted 1977), and relocation and trapping through 1967 (Hess 1993). Elk population levels were stabilized by hunting and culling to an average of 587 elk from 1953 to 1967 (Hess 1993). In 1968, the current natural regulation policy of elk management (i.e., no direct population management) was implemented, after which elk numbers again increased to 800-1200 animals, and successful aspen regeneration on core winter range became very infrequent (Baker and others 1997, Olmsted 1997). Since then, aspen has been observed to be in decline for much of the RMNP elk winter range. Decline is manifested as failure of new shoots to regenerate and grow to tree size, while overstory mortality continues at a rapid rate (Olmsted 1997).

The problem of aspen decline is not unique to Rocky Mountain National Park, but has been observed throughout the American West (Gruell and Loope 1974, Mueggler 1989, Romme and others 1995, Kay 1997a, White and others 1998). However, recent extensive surveys employing unbiased sampling techniques suggest that earlier studies may have underestimated the extent of aspen regeneration at the landscape level, for both Rocky Mountain National Park and the southern portion of the Greater Yellowstone Ecosystem ( $\mathrm{Su}-$ zuki and others 1999, Barnett and Stohlgren 2001). Aspen decline is commonly attributed to a combination of fire suppression and elk herbivory (Gruell and Loope 1974, Kay 1997a, Bartos and Campbell 1998). Fire suppression allows relatively long-lived, fast-growing conifers to overtop, and eventually replace, aspen in seral stands. Kay (1997a) suggested that aboriginal burning and effects of aboriginal hunters on reducing ungulate populations were responsible for the establishment of many aspen stands.

If there is an aspen regeneration problem in Rocky Mountain National Park, it is important that this problem be understood at the process level, to assist managers in making intelligent decisions. Ecosystem simulation models are valuable tools for synthesizing information about various ecological components in a holistic manner that makes explicit the interactions between components. The interaction that matters most for this study is the interaction between elk herbivory and aspen population dynamics. A model wellsuited for capturing that interaction as it unfolds over long time periods would allow us to: (1) better understand causal mechanisms for observed effects of elk on aspen dynamics; (2) forecast what would happen to aspen regeneration given different levels of elk herbivory and different assumptions about the effects of elk herbivory on aspen dynamics; and (3) identify gaps in our data and understanding that are critical for explaining and predicting elk effects on aspen dynamics.

The primary objective of this research was to use an existing ecosystem model (SAVANNA) to estimate levels of elk numbers that would be compatible with longterm, significant aspen regeneration. We also considered the effects of fencing aspen stands for varying time periods, and at different elk population levels following removal of fences.

\section{Materials and Methods}

\section{SAVANNA Model Adaptation}

The SAVANNA model is composed of interacting submodels for weather, soils, carbon, nitrogen, water, light, vegetation production and population dynamics, and ungulate production and population dynamics and has been applied to grassland, shrubland, savanna, and forested ecosystems (Coughenour 1992, Ellis and others 1993, Ellis and Coughenour 1998, Peinetti 2000, Weisberg and others 2002). The model represents, at a weekly time step: (1) vegetation dynamics as changes in plant functional group composition; (2) plant production in response to climatic variables, including seasonal patterns; (3) plant responses to herbivory; and (4) animal distribution, production, and population responses to climatic variables and changing patterns of plant production and vegetation composition. We used SAVANNA to model a single, 1-ha aspen stand over a range of elk densities (from 0 to 16 elk $\mathrm{km}^{-2}$ ). Results were extrapolated to the whole winter range using Arc/ Info GIS software, and GIS coverages for aspen stand locations and historical elk distribution.

We modeled three functional groups of plants (aspen, bunchgrasses, and forbs) and one animal species (elk). The focal organism was aspen (Figure 1), and other model elements were parameterized to be ecologically "sensitive" only insofar as they might influence aspen dynamics. For example, elk production, population dynamics, and energetics were not explicitly simu- 


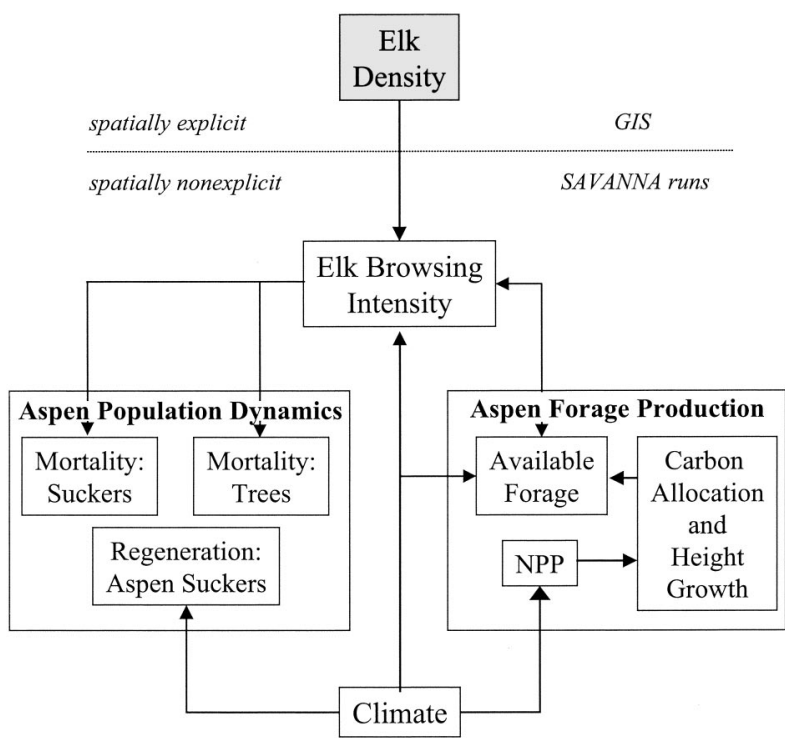

Figure 1. The conceptual framework for our adaptation of the SAVANNA model to the problem of elk herbivory on aspen in Rocky Mountain National Park.

lated. To explore the effects of different levels of elk herbivory on aspen, a fixed number of elk were maintained for a fixed time period in aspen stands. Since aspen represents only a small proportion $(7 \%$, Hobbs and others 1981) of the winter elk diet, it is realistic to exclude negative feedbacks of aspen browse availability on elk condition or population dynamics.

Key model parameters are presented in Table 1. It is beyond the scope of the paper to present the mathematical formulation of SAVANNA; for a detailed model description, see Coughenour (2001; available upon request from Rocky Mt. National Park, Estes Park, Colorado, USA).

Elk density was treated as a model input variable (Figure 1), derived from either aerial survey or simulated elk distribution data. Elk consumption of aspen was permitted to reach a maximum of $0.012 \mathrm{~kg}$ as$\mathrm{pen} / \mathrm{kg}$ elk/day (Table 1 ). This value was obtained by calibrating the model to achieve levels of aspen production and elk offtake observed by Olmsted (1997). However, elk intake rates generally did not reach the maximum value, and were calculated as (equation 1):

$$
I=I_{\text {max }} * \operatorname{MIN}\left(F_{\text {fresp }}, F_{\text {snow }}\right) * F_{\text {sat }}
$$

where $I$ is the intake rate $(\mathrm{kg}$ forage $/ \mathrm{kg}$ animal/day); $I_{\max }$ is the maximum intake rate ( $\mathrm{kg}$ forage $/ \mathrm{kg}$ animal/ day); $F_{\text {fresp }}$ is the effect of functional response (feedback of forage availability $\left(\mathrm{g} / \mathrm{m}^{2}\right)$ upon forage intake rate) (Spalinger and Hobbs 1992) $\left(0-1\right.$ scalar); $F_{\text {snow }}$ is the effect of snow depth $(\mathrm{cm})$ on forage intake rate multiplier $(0-1$ scalar $)$; and, $F_{\text {sat }}$ is the effect of satiation on forage intake rate $(0-1$ scalar).

Aspen population dynamics were modeled using six age classes in 10-year increments. Using this approach, it was feasible to consider the youngest age class as aspen suckers. Mortality rate parameters for the oldest age class were chosen to allow aspen to attain a maximum age of 150 years. Individual aspen trees can live for longer than 200 years (Jones and Schier 1985), but most aspen stands in the region are likely to succumb to senescence and disease and deteriorate by 150 years. Individual trees within classes are not modeled explicitly, although each class may be represented by a "mean tree." The maximum size for each class, with regard to stem diameter, canopy diameter, root diameter, upper canopy height, lower canopy height, stem biomass, total root biomass, fine root biomass, and fine twig biomass, was estimated using allometric equations and other information from a variety of sources (Table 1) (Beetle 1974, Olmsted 1977, Bartos and Johnson 1978, Ruark 1985, Wang and others 1995). Potential growth rates were set so that trees under reasonable growing conditions could grow from one age class to the next in 10 years. Actual growth rates are calculated according to a semimechanistic photosynthesis submodel, where net primary production (NPP) is influenced by light, water, temperature, nitrogen, and temperature. The NPP submodel is explicitly linked to a water budget submodel through transpiration and plant water use (Ball and others 1987). Allocation of NPP among plant tissues utilizes an allometric approach, where allometry varies with aspen age class (Table 1).

Aspen regeneration was modeled as occurring under two different mechanisms, both considered to represent suckering. Regeneration by seed was not considered a possibility, as it has very seldom been observed in the western United States, except following rare events such as extensive and severe wildfires (Kay 1993, Romme and others 1997). The first mechanism allows suckering to occur in the presence of an overstory. The maximum number of suckers per month, per living tree, is specified for each age/size class (Table 1). Unfortunately, there are no useful data on suckering rates of aspen in the absence of overstory mortality. Therefore, these age-class-specific values were calculated using data for stem density as a function of stand age (Shepperd 1990, 1993), on the assumption that 2000 suckers per hectare per year is a representative suckering rate under optimal conditions. The second mechanism requires setting suckering rates associated with overstory tree mortality, such that a specified number of suckers attempt to establish following mortality 
Table 1. Selected input parameters for the SAVANNA model as applied to this study. ${ }^{a}$ Where $(X, Y)$ pairs are given, these refer to user-input "table functions" where the modeled functional relationship is a linear interpolation between coordinate pairs (i.e., for a given $X$ value, a $Y$ value is interpolated). Where six values are listed continuously on a line, these refer to each of six age classes in 10-year increments add to ref list?

\begin{tabular}{|c|c|c|c|}
\hline Parameter & Value & Units & Source \\
\hline \multicolumn{4}{|c|}{ Foraging submodel } \\
\hline$I_{\max }$ & 0.012 & $\mathrm{~kg}$ forage/ $\mathrm{kg}$ animal/day & fit (see text) \\
\hline$F_{\text {fresp }}$ & $(0 ., 0),.(4.6,0.7),(15 ., 1)$. & $\left(\mathrm{gm}^{-2}\right.$ forage; unitless $)$ & fit (see text) \\
\hline$F_{\text {snow }}$ & $(5 ., 1),.(40 ., 0)$. & (cm snow depth; unitless) & Sweeney and Sweeney (1984) \\
\hline$R$ & 2.0 & $\mathrm{~m}$ & Murie 1951 \\
\hline \multicolumn{4}{|c|}{ Aspen allometry } \\
\hline$H$ & $2.00,5.81,6.83,7.67,8.38,13.0$ & $\mathrm{~m}$ & Olmsted (1977), Suzuki data \\
\hline$D_{c}$ & $0.60,1.10,1.30,1.50,1.95,3.60$ & $\mathrm{~m}$ & Beetle (1974) \\
\hline$D_{s}$ & $3.60,11.4,13.5,15.2,16.6,26.1$ & $\mathrm{~cm}$ & Olmsted (1977), Suzuki data \\
\hline$M_{L}$ & $0.08,0.29,0.48,0.70,1.20,5.10$ & $\mathrm{~kg}$ & Wang and others (1995) \\
\hline$M_{W}$ & 1.59, 26.6, 40.6, 56.6, 73.7, 212. & $\mathrm{~kg}$ & Wang and others (1995) \\
\hline$M_{\mathrm{FB}}$ & $0.08,0.14,0.30,0.44,0.76,3.21$ & $\mathrm{~kg}$ & Bartos and Johnson (1978) \\
\hline$M_{R}$ & $0.64,6.40,8.43,10.7,13.6,21.6$ & $\mathrm{~kg}$ & Ruark (1985) \\
\hline$M_{\mathrm{FR}}$ & $0.08,0.29,0.48,0.70,1.20,5.10$ & $\mathrm{~kg}$ & guess \\
\hline \multicolumn{4}{|c|}{$\begin{array}{l}\text { Aspen establishment } \\
\text { and mortality }\end{array}$} \\
\hline$E$ & $0.00,0.01,0.08,0.12,0.16,0.17$ & suckers/mo & see text \\
\hline$S$ & $0.00,0.02,1.62,2.45,3.33,3.39$ & suckers/mo & see text \\
\hline$F_{\text {watr }}$ & $(0.9,0),.(1 ., 1)$. & (relative water content; unitless) & Jones and others (1985) \\
\hline$F_{\text {temp }}$ & $(5 ., 0),.(11 ., 1)$. & $\left({ }^{\circ}\right.$ Celsius; unitless $)$ & Jones and others (1985) \\
\hline$F_{\text {herb }}$ & $(0 ., 1),.(410 ., 0)$. & (gm ${ }^{-2}$ biomass; unitless) & fit \\
\hline$F_{\mathrm{wcv}}$ & $(0 ., 1),.(0.4,0.2),(0.9,0.0)$ & (proportional cover; unitless) & fit \\
\hline$B$ & $(0 ., 0),.(0.2,1.0)$ & (proportion browsed; unitless) & fit (see text) \\
\hline$N_{m}$ & $0.28,0.02,0.02,0.02,0.02,0.02$ & proportion stems per year & fit \\
\hline
\end{tabular}

aAbbreviations: $I_{\max }=$ maximum intake rate; $F_{\text {fresp }}=$ effect of functional response (feedback of forage availability upon forage intake rate; Spalinger and Hobbs 1992); $F_{\text {snow }}=$ effect of snow depth on forage intake rate multiplier; $R=$ elk reach height (above snow level, if present); $H=$ tree height; $D_{\mathrm{c}}=$ crown diameter; $D_{\mathrm{s}}=$ stem diameter $(\mathrm{dbh}) ; M_{\mathrm{L}}=$ leaf biomass; $M_{\mathrm{W}}=$ wood biomass $\left(\right.$ stem + branch); $M_{\mathrm{FB}}=$ fine branch biomass; $M_{\mathrm{R}}=$ total root biomass; $M_{\mathrm{FR}}=$ fine root biomass; $E=$ maximum suckering rate per living tree per month; $S=$ maximum suckering rate per dying stem per month; $F_{\text {watr }}=$ effect of water (relative water content of soil) on establishment; $F_{\text {temp }}=$ effect of temperature on establishment; $F_{\text {herb }}=$ effect of herbaceous root biomass on establishment; $F_{\text {wcv }}=$ effect of woody canopy cover on establishment; $B=$ fraction of current annual growth browsed vs. fraction suckers killed; $N_{\mathrm{m}}=$ nominal (background) mortality rate.

of a tree in a given age/size class (Table 1). These values were based on a maximum suckering establishment rate, following complete overstory removal, of 40,000 suckers per hectare per year, as has been observed following fire (Bartos and Mueggler 1980). Simulated rates of establishment are further influenced by water availability, temperature, and competition with herbaceous plant species (equation 2) (Table 1):

$$
E f f=F_{\text {watr }} * F_{\text {temp }} * \operatorname{MIN}\left(F_{\text {herb }}, F_{\text {wev }}\right)
$$

where Eff is the effect of environmental factors on tree regeneration; $F_{\text {watr }}$ is the effect of available soil moisture; $F_{\text {temp }}$ is the effect of temperature; $F_{\text {herb }}$ is the effect of herbaceous root biomass; and $F_{\mathrm{wcv}}$ is the effect of woody canopy cover.

For this study, the main mortality influence on aspen suckers was modeled as the effect of elk herbivory. Simulated effects of elk herbivory on aspen included biomass effects and population effects. Biomass effects occurred when elk herbivory maintained aspen suckers at low heights and low levels of shoot biomass. Lower levels of elk herbivory allowed a number of suckers to grow beyond elk reach height and form a viable regeneration cohort. Population effects occurred when elk herbivory killed aspen suckers according to a specified relationship between the proportion of the sucker browsed and the probability of sucker mortality (Table $1)$. Sucker mortality probability was simulated as 1.0 when $20 \%$ of the sucker woody biomass was browsed. This value is similar to the "breakeven level" of $30 \%$ twig volume reduction proposed by Olmsted (1977, 1997), where aspen stands in the study area with greater reduction were more likely to have experienced declining stand density over the 20-year period of study. The $20 \%$ value was arrived at through the model calibration process described below, by starting with the $30 \%$ Olmsted value, and then allowing the parameter to vary until simulated results for aspen production most 
closely matched observed results. Elk-induced mortality of older trees (e.g., from bark-stripping) was not represented, suggesting that our results for elk effects on aspen may be conservative.

\section{Model Calibration and Testing}

The model was calibrated and tested using data for nine aspen stands on elk winter range in RMNP, for which long-term data were available for aspen production, elk offtake of aspen, and aspen sucker density. These sites were originally sampled in 1975-1976 (Olmsted 1977), and resampling occurred in 1985-1986 and 1995-1996 (Olmsted 1997). Specific information for each site used in model calibration were its elevation, slope steepness, slope aspect, winter elk density (see below), canopy cover in 1975-1976, and age class structure in 1975-1976. Except for elk density, this information comes from Olmsted (1977), Olmsted (1997), and unpublished data from Olmsted's work.

Winter elk densities for model calibration were obtained from spatially explicit SAVANNA runs of elk distribution, utilizing habitat suitability algorithms that include forage availability (total forage biomass, herbaceous green biomass), slope steepness, modeled climatic variables (snow depth, mean daily temperature), and the existing density of elk on a particular patch. Outputs from spatially explicit SAVANNA runs were at a 25-ha resolution, coarser than the 1-ha resolution of the GIS coverage used for delineating aspen stands. Average annual winter elk density for each aspen stand was calculated as the mean simulated elk density at that location, from January to April, for each year from 1970 to 1998 .

We simulated aspen dynamics at the nine sites from 1970 to 1998 , using historical weather data. Observed data for aspen production and elk offtake were available for the winters of 1975-1976, 1985-1986, and 1995-1996 (Olmsted 1997). For these three seasons, we compared observed and simulated shoot production of current year's growth on all twigs up to $2 \mathrm{~m}$ in height. Observed shoot production, measured in October, was provided in units of twig volume. We converted twig volume (cubic centimeters) to twig wet weight (grams) using the empirical relationship from Olmsted (1977) (equation 3):

$$
\text { Weight }=(0.671 * \text { Volume })+0.236
$$

Elk intake rate for aspen was calibrated until there was reasonable agreement between observed and simulated elk offtake. Observed elk offtake for the winter months was calculated as the difference between twig volume measured in October and twig volume mea- sured in May of the following year, converted to units of weight.

We conducted statistical testing of model outputs, using all nine sites. This does not represent an independent validation, since all sites were used in model calibration, but does provide some indication as to the predictive ability of the model, for this particular application. A statistical validation of SAVANNA for a nearby area in northern Colorado is reported in Weisberg and others (2002), where simulated herbaceous biomass and offtake by elk closely matched observed data from a controlled grazing field experiment. The basic model operation has been validated elsewhere, in various studies (e.g., Ellis and others 1993, Coughenour 2001, Boone and others 2002). For the RMNP application, we used environmental and stand structural data specific to each site, and compared aspen sucker production, sucker density, and winter elk offtake from aspen suckers between observed and simulated data. Aspen sucker density and offtake data were sufficiently skewed to require square root and logarithmic transformations, respectively, prior to statistical validation.

We also analyzed the sensitivity of aspen canopy cover, aspen sucker production, and aspen sucker density, to variation in several of the key input parameters. Following Friend and others (1993), each parameter was increased $\left(P_{1}\right)$ and decreased $\left(P_{0}\right)$ by $10 \%$, and a sensitivity index calculated as (equation 4$)$ :

$$
\beta^{\prime}=\frac{R_{1}-R_{0}}{R_{0}} / \frac{P_{1}-P_{0}}{P_{0}},
$$

where $R$ is the response variable, $R_{0}=R$ when the parameter is $P_{0}$, and $R_{1}=R$ when the parameter is $P_{1}$.

\section{Simulation Experiments}

The 1970-1988 calibration runs for the Beaver Meadows-Deer Ridge (BMDR) and Lower Beaver Meadows (LBM) sites were used to initialize a set of experimental runs for the 2000-2059 period. These two sites were chosen to represent different aspen stand structures now present on the winter range. The BMDR site (i.e., senescent stand) has an older age structure representative of decadent lower-elevation aspen stands in the park, having a moderate level of crown cover, a moderate to high winter elk density, and lacking successful establishment of a regenerating aspen cohort. The LBM site (i.e., young stand) represents aspen stands including a younger age cohort of aspen, due to successful aspen regeneration during the herbivore population control period of the $1950 \mathrm{~s}$ and $1960 \mathrm{~s}$ (Olmsted 1977). The great majority of aspen stands on 
core winter range more closely resemble the BMDR site (Baker and others 1997).

The seasonal duration of elk habitat use of RMNP winter range aspen is surprisingly little known, so we simulated multiple scenarios reflecting different assumptions. For the heavy use scenario, elk densities in the simulated aspen stand are at their maximum level for November, December, January, February, March, and April; at $80 \%$ of their maximum level for October; at $50 \%$ of their maximum level for May and September; and at $10 \%$ of their maximum level for June, July, and August. This general pattern of elk distribution is consistent with a recent, detailed study of elk movements (Larkins 1997), but it may be not be representative where aspen stands are utilized for shorter periods during winter and not at all during summer. Therefore, we also simulated a light use scenario, where elk densities are at their maximum level for December and January; at $50 \%$ of their maximum level for November and February; and are at 0 for the rest of the year. A field survey of winter elk movement and habitat use in the park found elk use of aspen stands to be substantial (as much as $35 \%$ of total habitat use) from October through December, but virtually zero from January through April, when elk increased their use of grassland habitats (Clarke and others 1994). These results suggest the light use scenario may more accurately describe elk use of aspen stands. We also simulated a moderate use scenario, where elk densities are maximal from January through April; at $50 \%$ of their maximum level for May, November, and December; and are at 0 from July through October.

Fence scenarios were simulated by setting elk population density to zero for the duration of the fencing treatment $(10,20$, or 30 years $)$, and then setting elk population density to the specified level upon completion of the treatment. All fence experiments used the Moderate Use scenario for elk use, and simulated senescent stands.

Experimental runs used randomized weather patterns with a mean and variance for temperature and precipitation similar to that of the 1910-1998 period. Elk density was systematically varied between 0 and 16 $\mathrm{elk} / \mathrm{km}^{2}$ for nine simulation experiments (Table 2).

\section{Data Analysis}

To explore how various treatments affected the probability of aspen persistence, we calculated the proportion of 60-year, random weather runs where the simulated aspen stand successfully regenerated. An aspen canopy cover of at least $40 \%$ was considered a necessary condition for regeneration success, while a canopy cover of at least $60 \%$ was considered a sufficient
Table 2. Simulation experiments conducted using the SAVANNA model ${ }^{a}$

\begin{tabular}{llll}
\hline $\begin{array}{l}\text { Elk density } \\
\left(\text { per } \mathrm{km}^{2}\right)\end{array}$ & $\begin{array}{l}\text { Level of } \\
\text { elk use }\end{array}$ & $\begin{array}{l}\text { Duration } \\
\text { of fence } \\
\text { period }(\mathrm{yr})\end{array}$ & $\begin{array}{l}\text { Simulated } \\
\text { aspen stand }\end{array}$ \\
\hline $0-16$ & Heavy & 0 & BMDR \\
$0-16$ & Moderate & 0 & BMDR \\
$0-16$ & Light & 0 & BMDR \\
$0-16$ & Heavy & 0 & LBM \\
$0-16$ & Moderate & 0 & LBM \\
$0-16$ & Light & 0 & LBM \\
$0-16$ & Moderate & 10 & BMDR \\
$0-16$ & Moderate & 20 & BMDR \\
$0-16$ & Moderate & 30 & BMDR \\
\hline
\end{tabular}

${ }^{a}$ All experiments ran for 60 years, using 20 stochastic weather replicates. BMDR refers to the senescent Beaver Meadow-Deer Ridge stand, while LBM refers to the Lower Beaver Meadows stand, which includes a younger aspen cohort. See text for explanation of elk use levels.

condition. Note that the initial (1976) aspen canopy cover values for the BMDR and LBM stands were $50 \%$ and $58 \%$, respectively. Where aspen canopy cover was between $40 \%$ and $60 \%$, regeneration success was considered to have occurred if one of the following conditions were true: (1) sucker density $\geq 1000 /$ ha; (2) age class 2 (11-20 years) density $\geq 500$ stems/OK? 500 stems/ha; (3) density $\geq 1000$ stems/ha in age classes 3 (21-30 years), 4 (31-40 years), and 5 (41-50 years) combined; and (4) density $\geq 300$ stems/ha each for $\geq$ 3 age classes from age class 3 to age class 6 (51-150 years). While these criteria are somewhat arbitrary, they guarantee that only those stands are considered to have successfully regenerated that have either increased in cover after 60 years or have maintained most of their original cover while younger cohorts have established.

Stand-level results were extrapolated to the landscape scale, over the extent of elk winter range within park boundaries, in the Estes Valley area. The official RMNP GIS coverage for vegetation, based on 1987 aerial photography and estimated to be $80 \%-85 \%$ accurate, was used to represent the distribution of aspen stands at a 1-ha resolution. Aspen stands are likely underrepresented by this vegetation coverage, since they are often quite small (Stohlgren and others 1997). The aspen data layer was overlaid on two coverages of mean relative elk density, each obtained using two data sources: (1) aerial surveys of winter elk distribution from 1994 to 1998; and, (2) simulated elk density from spatially explicit SAVANNA runs of elk distribution from 1960 to 1998, as described in the Model Calibration and Testing section. Results from each method are interpreted and reported separately, to provide an indication of the sensitivity of our interpretations to the 
A

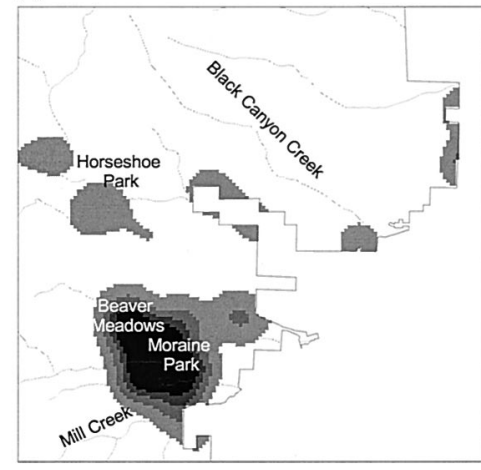

B

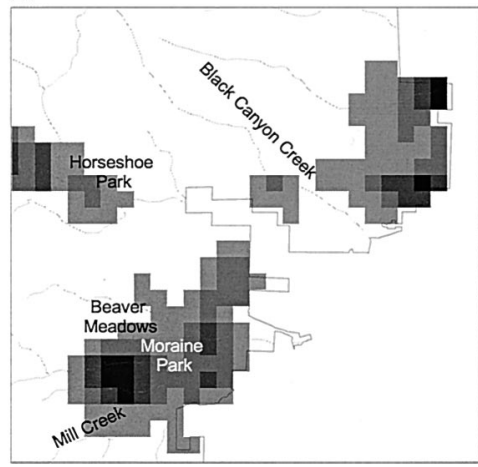

Aerial Survey, 1994 - 1998

\section{Relative Elk Density} (standard deviation units) $\square-1-0$

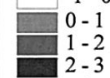
$\bigwedge_{N}$

Simulated Distribution 1960 - 1998

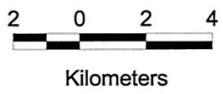

Figure 2. Maps of elk distribution (elk density, scaled to standard deviation units). (a) based on mean February elk density for the 1994-1998 period, estimated from aerial surveys (Singer and others 1998); and (b) based on SAVANNA simulations of winter (January-April) elk distribution, 19601998.

estimated spatial distribution of elk, a highly uncertain parameter.

Winter elk densities derived from 1994 to 1998 aerial survey (i.e., empirical) data were interpolated for each winter across all 1-ha pixels, in the portion of elk winter range within park boundaries, using standard GIS operations (Figure 2a). Interpolated elk density averaged over the 5 years was used to calculate a map of relative elk distribution, which was then used to predict elk population for each pixel, based on an overall elk population level for the RMNP winter range. Elk population level for each pixel was predicted as (equation 5):

$$
n_{i}=\left(\rho_{i} / \sum \rho\right) * N_{y}
$$

where: $n_{\mathrm{i}}$ is the number of elk occupying pixel $i ; \rho_{\mathrm{i}}$ is interpolated mean 1994 to 1998 elk density for pixel $i$; $\Sigma \rho$ is the sum of interpolated 1994 to 1998 elk densities over all pixels on the Park winter range; and $N_{\mathrm{y}}$ is the elk population level for the park winter range as a

whole, which was varied systematically from 100 to 3000 .

Elk population levels for each pixel using the simulated elk distribution data were also calculated using equation 5 , except that, in this case, $\rho_{\mathrm{i}}$ is the simulated mean elk density for one of three historical time periods, representing different elk population levels for the RMNP winter range as a whole: 1960-1975 (400-600 elk), 1975-1982 (600-1000 elk), 1982-1998 (1000-1400 elk). This approach permits the relative distribution of elk to change as total elk population changes.

Then, the expected probability of aspen regeneration success was estimated for each stand given its estimated elk population level, according to threshold values derived from simulation results. One-hectare aspen stands with a regeneration success probability of $\geq 90 \%$, or $\leq 10 \%$ were separated from other aspen stands, and the spatial pattern of aspen regeneration success was shown in map form, under different assumptions concerning elk population level, elk distribution patterns, seasonal intensity of elk use, and developmental stage of aspen stands.

The proportion of regenerating aspen stands on the winter range was described graphically, for heavy use and light use scenarios, and for elk population levels from 100 to $3000 \mathrm{elk} / \mathrm{km}^{2}$. Given a study area of ca. 107 $\mathrm{km}^{2}$, the 100-elk level would represent a density of about $1 \mathrm{elk} / \mathrm{km}^{2}$, while the 3000 elk level would represent a density of about $28 \mathrm{elk} / \mathrm{km}^{2}$, if elk density were homogeneous over the winter range. However, elk density over the winter range is far from homogeneous (Figure 2). For example, using the empirical data, an overall population level of 1219 elk in 1998 corresponded to a density of about $7 \mathrm{elk} / \mathrm{km}^{2}$ at the BMDR site, but to a density of about $56 \mathrm{elk} / \mathrm{km}^{2}$ at the heavily utilized Moraine Park site.

\section{Results}

\section{Model Testing}

A sensitivity analysis found that model outputs for aspen canopy cover, aspen sucker production, and aspen sucker density were especially sensitive to the userdefined function specifying the relationship between browsing intensity and aspen sucker mortality (Table 3). Sucker production and density were also quite sensitive to the other parameters tested, representing different aspects of aspen population dynamics. Aspen canopy cover was the least sensitive of the three response variables tested, supporting its use as the primary criterion for specifying simulated aspen regeneration success. 
Table 3. Sensitivity of aspen canopy cover, aspen sucker production, and aspen sucker density to selected model input parameters ${ }^{a}$

\begin{tabular}{llll}
\hline & $\begin{array}{l}\text { Aspen } \\
\text { Canopy } \\
\text { Cover }\end{array}$ & $\begin{array}{l}\text { Aspen } \\
\text { Sucker } \\
\text { Production }\end{array}$ & $\begin{array}{l}\text { Aspen } \\
\text { Sucker } \\
\text { Density }\end{array}$ \\
\hline$E$ & 0.32 & 4.84 & 4.47 \\
$S$ & 0.18 & 4.26 & 4.11 \\
$I_{\max }$ & -3.53 & -4.17 & -4.09 \\
$B$ & 15.18 & 33.20 & 29.78 \\
$N_{m}$ & -3.78 & -4.02 & -3.92 \\
\hline
\end{tabular}

${ }^{\mathrm{a}}$ For parameter abbreviations and values used in the model, see Table 1.

Based on the statistical testing of model predictions for the nine sites, mean aspen production does not differ significantly between observed and simulated values for any of the years considered (Table 4). Coefficients of determination for the regression fit between observed and simulated production values range from 0.62 to 0.91 . The simultaneous $F$ test for regression bias indicates that the hypothesis of a biased model cannot be rejected for the 1995-1996 season, and confidence intervals for regression slope do not include 1.0 for all years except 1975-1976. These results suggest that, with regard to aspen production, the model generates quite reasonable results with a minor but significant bias, where the model underpredicts for low values, but overpredicts for high values, of aspen production (Figure $3 \mathrm{a})$.

Mean elk offtake of aspen does not differ significantly from observed offtake, although simulated offtake is lower for all years (Table 5). While validation results appear acceptable when only mean values are considered, the model poorly predicted offtake at a given site for a given year (Table 5, Fig. 3b). The model underpredicts offtake at low values, there is a wide scatter around the line of perfect fit, and linear regression relationships between observed and predicted offtake are not significant for individual years. We attribute the poor performance of the model at this level to uncertainty associated with elk density for a given site and year. Simulated elk distributions may be accurate as generalizations, but lack sufficient precision to predict the number of elk at a fine temporal and spatial resolution. This is demonstrated by the occurrence of high observed offtake values in the Olmsted (1997) data set, for particular sites and winters for which no or few elk were predicted. For example, elk offtake of aspen at the Little Horseshoe Park (LHRS) site was observed by Olmsted (1997) to be $15.49 \mathrm{~g} / \mathrm{m}^{2}$ in $1975-1976$, while estimates of mean elk density for that winter at that site were only 2.88 and $5.01 \mathrm{elk} / \mathrm{km}^{2}$ using the empirical and simulation elk distribution methods, respectively. Even though 1975 aspen sucker production was predicted fairly accurately for this site $\left(19.53 \mathrm{~g} / \mathrm{m}^{2}\right.$ observed vs $17.13 \mathrm{~g} / \mathrm{m}^{2}$ predicted), there would be no chance for the model to predict offtake accurately given available estimates for mean elk density. However, errors associated with incorrect estimates of elk density may average out over the 60 -year period of the experimental runs and at the scale of the entire winter range.

Model output for aspen sucker density is not directly comparable with observed aspen density, since observed aspen density includes suckers of very small size, while simulated aspen suckers have minimum heights and crown diameters of $0.5 \mathrm{~m}$ and $0.15 \mathrm{~m}$, respectively. However, observed and simulated sucker density are positively associated according to the following linear regression relationship $\left(R^{2}=0.45 ; F_{(1,25)}=20.73 ; P<\right.$ 0.01) (equation 6):

$$
y=2.61 x+48.09
$$

where $y$ is the square-root transformed observed aspen sucker density, and $x$ is the square-root transformed simulated aspen sucker density.

\section{Stand-Level Results}

Aspen regeneration success is clearly much greater when elk use is less prolonged over the course of the year (Figure 4a). Under the heavy use scenario, aspen regeneration success for the senescent stand is high at $1 \mathrm{elk} / \mathrm{km}^{2}$, moderate at $2 \mathrm{elk} / \mathrm{km}^{2}$, and decreases sharply between 2 and $3 \mathrm{elk} / \mathrm{km}^{2}$. For this same stand under the moderate use scenario, aspen regeneration success is still moderate at $3 \mathrm{elk} / \mathrm{km}^{2}$, is low at $4 \mathrm{elk} /$ $\mathrm{km}^{2}$, and is 0 at densities of $5 \mathrm{elk} / \mathrm{km}^{2}$ or greater. Under the light use scenario, simulated aspen at the senescent stand has a greater than $50 \%$ chance of regeneration at densities of up to $5 \mathrm{elk} / \mathrm{km}^{2}$, but declines gradually to 0 by $8 \mathrm{elk} / \mathrm{km}^{2}$.

An alternative means of estimating elk density levels beyond which senescent aspen stands may decline is through the analysis of simulated aspen canopy cover (Figure 5a). By the end of the 60-year simulations, mean aspen canopy cover has dropped sharply below the initial level of $50.5 \%$ at densities of $3 \mathrm{elk} / \mathrm{km}^{2}, 4$ $\mathrm{elk} / \mathrm{km}^{2}$, and $6 \mathrm{elk} / \mathrm{km}^{2}$, for heavy use, moderate use, and light use scenarios, respectively.

The probability of aspen regeneration success despite moderate or high levels of elk browsing increases greatly if a younger aspen age cohort is present (Figure $4 b)$. For such stands, aspen regeneration success under the heavy use scenario is $\geq 0.90$ for up to $3 \mathrm{elk} / \mathrm{km}^{2}$, 
Table 4. Statistical comparison of simulated and observed data for aspen production $\left(\mathrm{g} / \mathrm{m}^{2}\right)^{\mathrm{a}}$

\begin{tabular}{lllll}
\hline Winter Season & $1975-1976$ & $1985-1986$ & $1995-1996$ & Overall \\
\hline Number of observations & 9 & 9 & 9 & 27 \\
Mean (simulated) & 6.88 & 4.41 & 2.20 & 4.50 \\
Mean (observed) & 7.33 & 3.63 & 2.49 & 4.48 \\
Paired $t$ test statistic & 0.54 & -0.61 & 0.33 & -0.03 \\
$\quad(2-s i d e d ~ P$ value) & 0.60 & 0.56 & 0.75 & 0.98 \\
Regression $R^{2}$ & 0.91 & 0.62 & 0.83 & 0.76 \\
Regression slope & 1.11 & 0.50 & $0.30-0.71$ & 0.80 \\
$\quad 95 \%$ CI & $0.77-1.45$ & $0.15-0.85$ & 7.94 & $0.61-0.98$ \\
Regression Bias F & 0.78 & 2.83 & 0.02 & 0.29 \\
$\quad$ Pvalue & 0.50 & 0.15 & & 0.29 \\
\hline
\end{tabular}

${ }^{a}$ The paired $t$ test tests the hypothesis that the mean difference between simulated and observed values is 0 . All regression relationships between observed and predicted values are significant at $\alpha=0.01$. The simultaneous $F$ statistic for model bias tests the hypothesis that slope $=1$ and intercept $=0$.

$\geq 0.50$ for up to $7 \mathrm{elk} / \mathrm{km}^{2}$, and 0 by $9 \mathrm{elk} / \mathrm{km}^{2}$. Simulated aspen canopy cover drops significantly below its initial value of $57.5 \%$ by $8 \mathrm{elk} / \mathrm{km}^{2}$, (Figure $5 \mathrm{~b}$ ). Under the moderate use scenario, aspen regeneration success is $\geq 0.90$ for up to $4 \mathrm{elk} / \mathrm{km}^{2}, \geq 0.75$ for up to $7 \mathrm{elk} /$ $\mathrm{km}^{2}$, then drops off sharply, reaching 0 by $12 \mathrm{elk} / \mathrm{km}^{2}$. Simulated aspen canopy cover drops to $40 \%$ by 8 elk/ $\mathrm{km}^{2}$, and drops sharply lower to about $20 \%$ by 10 $\mathrm{elk} / \mathrm{km}^{2}$. Aspen regeneration success for the light use scenario does not drop below 0.40 by the maximum elk density tested, of $16 \mathrm{elk} / \mathrm{km}^{2}$ (Figure $4 \mathrm{~b}$ ). At least $90 \%$ of simulation stands regenerated at density levels of up to $7 \mathrm{elk} / \mathrm{km}^{2}$. Simulated canopy cover drops slightly below its initial level at a density of $14 \mathrm{elk} / \mathrm{km}^{2}$ (Figure $5 \mathrm{~b}$ ).

Aspen regeneration success is also significantly improved by fencing senescent aspen stands (Figure 4c). As might be expected, fencing aspen stands for longer time periods improves the probability of aspen persistence. Fencing for 10 years, followed by a 50 -year period without fences, does not much improve the probability of aspen persistence relative to a control scenario of no fencing at all. However, aspen regeneration probability does not appear to be ensured even at moderate elk densities with the 30 -year fence scenario. This is because the aspen stands again begin to deteriorate, once the fences come down.

\section{Landscape-Level Results}

The landscape-level results for the proportion of regenerating aspen stands (i.e., PRegen $=$ at least a $90 \%$ probability of regenerating) as a function of winter range elk population level show similar patterns, regardless of whether elk distributions are derived from empirical or simulated data (Figures 6 and 7). However, PRegen using the simulated distributions shows more of a steady rise with decreasing elk population, for elk population levels below about 600 elk (heavy use-senescent stands), 900 elk (light use-senescent stands), and 1300 elk (light useyounger stands). PRegen also is generally lower using the simulated elk distribution data (Figure 6). This is because simulated elk distribution is less concentrated than that derived directly from empirical data (Fig. 2), but is also more focused on aspen stand locations. Simulated elk distributions also are output at a coarser resolution (25 ha) than that produced by the empirical GIS interpolation (1 ha), resulting in the steplike response curves shown in Figure $6 b$.

The heavy use scenario yields the interesting result that PRegen for senescent stands is little affected by elk population level (Figures 6 and 7), except at levels below about 300 elk, where empirical data are used to specify elk distributions (Figure 6a), or below about 600 elk where simulated elk distributions are used (Figure $6 \mathrm{~b})$. Using the empirical distributions, fewer than $60 \%$ of senescent aspen stands have a $\geq 90 \%$ probability of regenerating even at 200 elk, although most of the remaining stands $(85 \%)$ have at least a $10 \%$ probability of regenerating (Figure 7). Using the simulated elk distributions, PRegen at 200 elk is even lower.

The landscape-level results for the moderate use scenario are only slightly different from those of the heavy use scenario and are not shown in Figures 6 and 7 . There is a greater difference between elk population extremes for senescent stands, given the light use scenario (Figures 6 and 7). Given the empirical elk distributions, there is little effect of elk population level on PRegen until population levels of below about 500 elk have been reached (Figure 6a). Given the simulated elk distributions, there is a 10\% increase in PRegen as elk population level is reduced from 1000 to 900 , and then little effect of elk population on PRegen until about 400 elk, below which PRegen increases markedly (Figure 6b).

Younger stands (dashed lines on Figure 6) are better able to perpetuate themselves under elk browsing pres- 
Figure 3. Model verification, using data derived from field observations of aspen sucker volume production, for three winters at decadal intervals, over nine sites (Olmsted 1997). (a) Comparison of observed vs simulated aspen sucker production (current annual growth up to $2 \mathrm{~m}$ in height); (b) comparison of observed vs. simulated elk offtake of aspen. The data have been transformed using the natural logarithm.
A Aspen Sucker Production

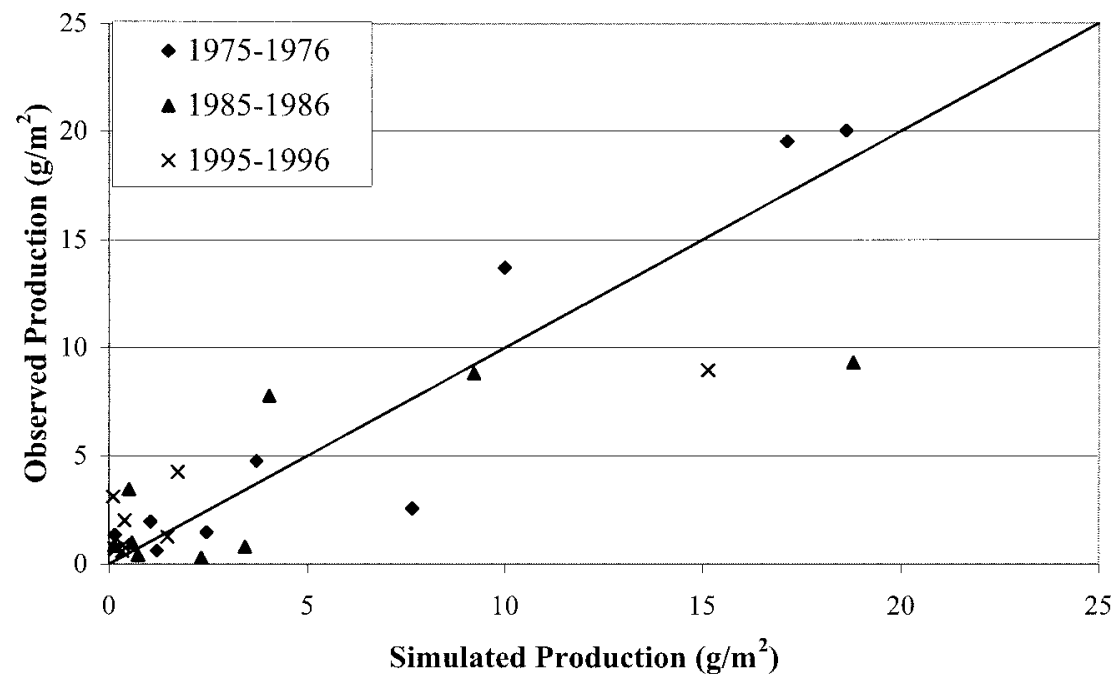

B Elk Offtake of Aspen (logarithmic transformation)

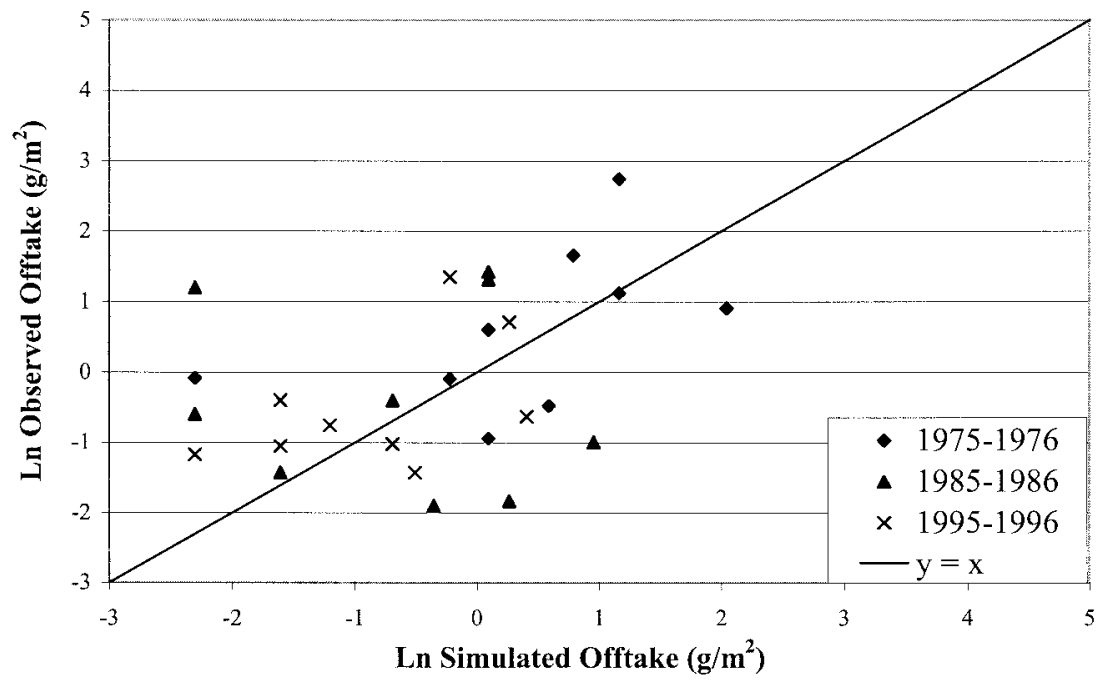

sure than senescent stands. Since the threshold value of $90 \%$ aspen regeneration probability is $3 \mathrm{elk} / \mathrm{km}^{2}$ for both heavy use-senescent stands and light use-younger stands scenarios (Figures 4a,b), these two scenarios produce identical results for landscape-level PRegen. The light use-younger stands scenario shows PRegen increasing significantly with decreasing elk population levels below population levels of about 1000 elk (empirical elk distributions) or 800 elk (simulated elk distributions) (Figure 6).

At approximately current elk population levels (10001200 elk), only $35 \%-45 \%$ of senescent aspen stands are simulated as having a $90 \%$ probability of regeneration success (Figure 6). Nearly all of these are located on the periphery of the winter range (Figure 7). Given the heavy use scenario, most of the difference between the 200 and 1000 elk population levels occurs for aspen in the vicinity of Horseshoe Park and Beaver Meadows, although some stands in these areas still fail to regenerate even at the lower elk levels (Figure 7). Given the light use scenario, the only stands that fail to regenerate at $200 \mathrm{elk}$ are in Moraine and Horseshoe Parks.

\section{Discussion}

\section{Elk Distribution Patterns and Aspen}

The landscape-level analysis suggests that senescent aspen stands at lower elevations on the core winter 
Table 5. Statistical comparison of simulated and observed data for elk offtake of aspen $\left(\mathrm{g} / \mathrm{m}^{2}\right)^{\mathrm{a}}$

\begin{tabular}{|c|c|c|c|c|}
\hline Winter Season & $1975-1976$ & $1985-1986$ & 1995-1996 & Overall \\
\hline Number of observations & 9 & 9 & 9 & 27 \\
\hline Mean (simulated) & 2.36 & 0.86 & 0.61 & 1.27 \\
\hline Mean (observed) & 3.43 & 1.48 & 0.98 & 1.96 \\
\hline Paired $t$-test statistic & 0.56 & 0.47 & 1.11 & 1.11 \\
\hline 2-sided $P$ value & 0.59 & 0.65 & 0.30 & 0.28 \\
\hline Regression $R^{2}$ & NS & NS & NS & 0.15 \\
\hline Regression slope & NS & NS & NS & 0.39 \\
\hline $95 \%$ CI & NS & NS & NS & $0.01-0.77$ \\
\hline Regression bias $\mathrm{F}$ & NS & NS & NS & 0.37 \\
\hline$P$ value & NS & NS & NS & 0.69 \\
\hline
\end{tabular}

${ }^{a}$ Original units are reported for mean values, although all statistical analyses use logarithmically transformed values. The paired $t$ test tests the hypothesis that the mean difference between simulated and observed values is 0 . Only regression relationships between observed and predicted values significant at $\alpha=0.05$ are shown. The simultaneous $F$ statistic for model bias tests the hypothesis that slope $=1$ and intercept $=0$.

range, that are not successional to conifers and occur as isolated forest patches within a grassland matrix, may be in jeopardy except at extremely low elk population levels (Figures 6 and 7). This is because elk distribution in the winter range is highly aggregated (Figure 2), so that a high density of elk occupy Horseshoe Park, Beaver Meadows, and Moraine Park, even at low population levels overall. For example, model results suggest the heavily utilized Moraine Park aspen stand would have less than a $10 \%$ probability of successful regeneration even at 200 elk, under either the heavy or moderate use scenarios. If elk distribution in winter is actually as aggregated as Figure 2 suggests, then maintenance of declining aspen stands may require management intervention at a local scale. Reductions of the elk herd at the scale of the whole winter range may have little effect on aspen regeneration success in core winter range areas. The only scenarios where reductions of overall elk population level below current levels (approximately 1000) were simulated as having a relatively continuous effect on the probability of aspen regeneration were those involving aspen stands that included a younger $(<30$ years old $)$ cohort. Such stands are now exceedingly rare on core winter range (Baker and others 1997).

Furthermore, aspen stands on the periphery of elk winter range maintain low levels of elk density, and so have high aspen regeneration probabilities even at high elk population levels overall, provided they are not overtopped by conifers, a process we did not simulate (Figure 7). This result agrees with field observations of Suzuki and others (1999), who observed ample aspen regeneration on peripheral elk winter range in RMNP.

\section{Data Gaps and Model Uncertainty}

This model application has helped to identify critical gaps in our understanding of elk-aspen interactions in
RMNP. The effect of elk herbivory on aspen sucker mortality has been insufficiently quantified but is a parameter to which the model is extremely sensitive (Table 3). Also relatively unknown is the effect of bark removal by elk on long-term survival of mature aspen trees of different sizes and ages. It would also be useful to know much more about aspen suckering rates, both under a closed aspen canopy, as well as in disturbed stands. Ideally, this should be studied in exclosures, to allow quantification of maximum potential rates of aspen sucker establishment, under different climatic conditions.

Our results clearly show that the seasonal extent of elk use of aspen stands is a very important driving variable, if we are to understand the impacts of elk on long-term aspen dynamics. We need to learn more about elk use of aspen for forage and cover in RMNP over time scales from hours to years.

While more empirical research needs to be done on certain key model parameters before we can confidently forecast the results of a given management scenario, our modeling results represent an integration of a vast amount of available data, and our best assessment at this time. Ideally, the modeling effort should evolve in synchrony with field research designed to reduce our uncertainty about critical processes and causal relationships. Unfortunately, certain key model parameters and inputs (e.g., elk distribution at fine spatial scales) may never be known for the historical period over which the model can be verified using time series or repeat sampling data.

\section{Implications for Elk and Aspen Management}

Implications of these results for elk and aspen management in RMNP depend very much on the specific nature of management goals. Management goals addressing RMNP's mandate to “ try to maintain all the components and processes of naturally evolving park ecosystems, including the natural abundance, diversity, 
A No Fences, Senescent Stand

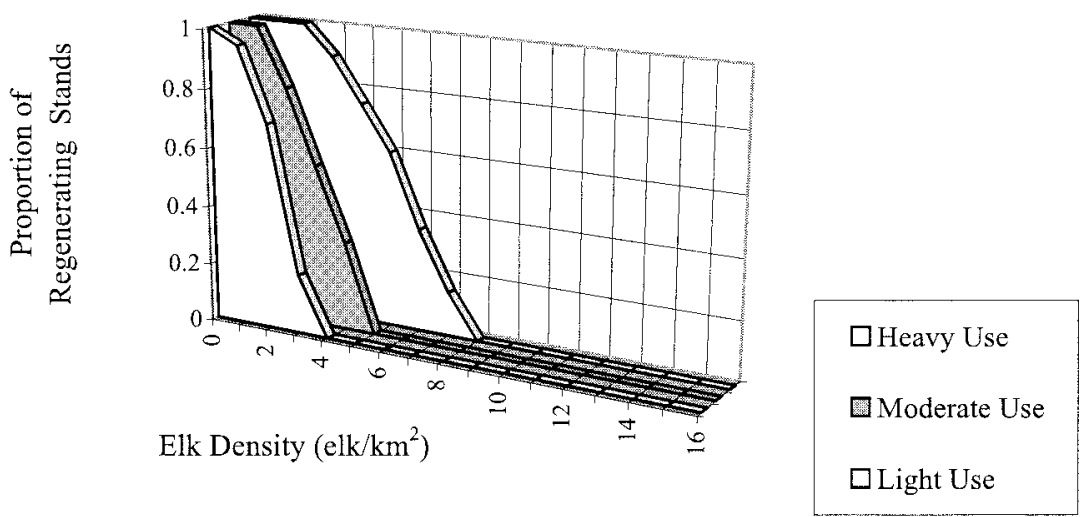

B No Fences, Stand with a Younger Cohort

Figure 4. Aspen regeneration success for different levels of elk density. The heavy, moderate, and light use treatments refer to the duration of elk access to the aspen stand over the course of the year (see text for detailed explanation). The proportion of regenerating stands ( $y$ axis) refers to the propotion of stochastic simulation runs where the simulated aspen stand successfully regenerated by the end of the 60-year simulation runs (see text for detailed explanation). (a) Reported for heavy, moderate, and light use treatments, for senescent aspen stands without fences; (b) as for (a), but for stands with a younger cohort present; (c) for fencing scenarios of varying duration, followed by a moderate level of seasonal elk use. Elk densities are those following removal of fences.

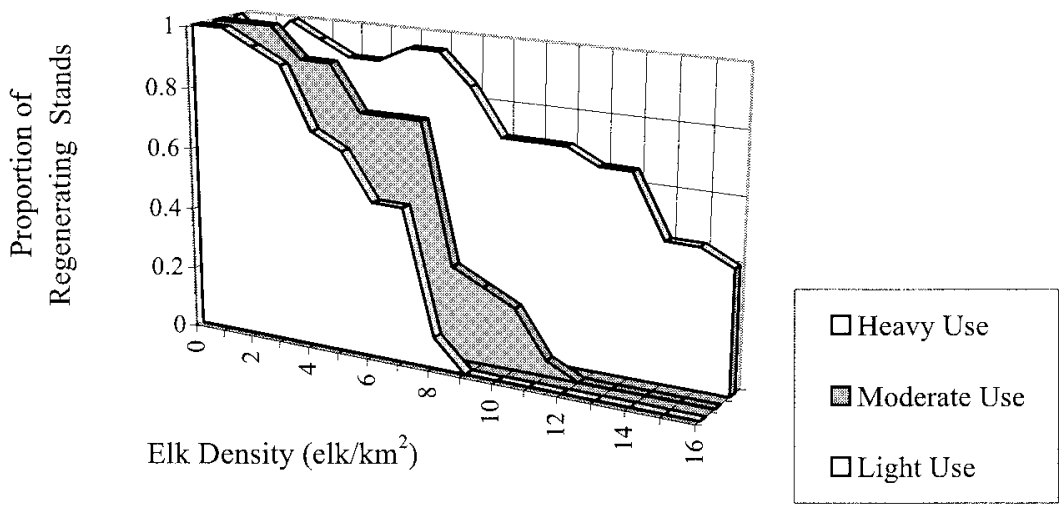

C Moderate Use After Fences, Senescent Stand

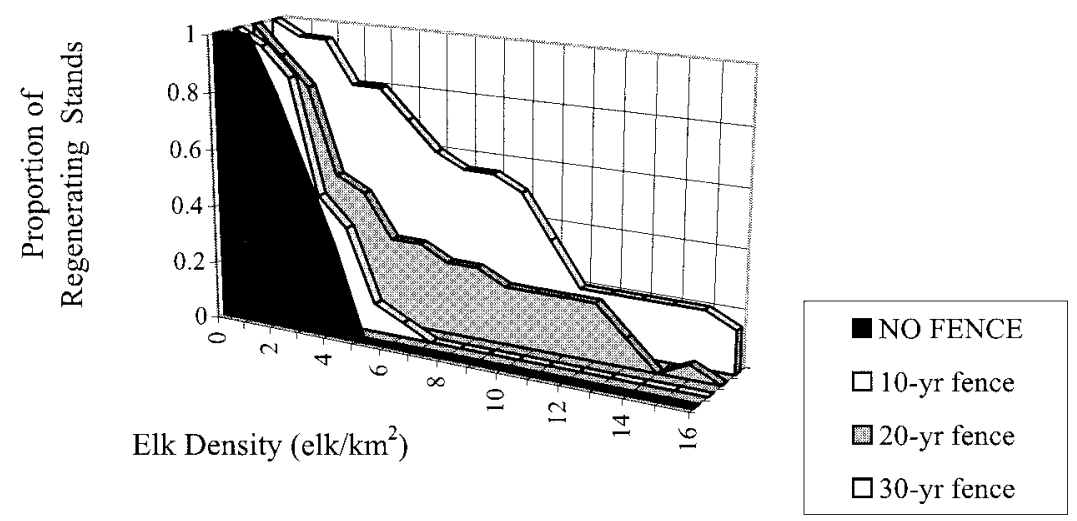

and ecological integrity of plants and animals" (National Park Service 1988), may be expressed along a gradient of complexity and spatial resolution. The specific goal might be to: (1) maintain aspen as a species on RMNP winter range; (2) maintain a component of valley bottom and dry park aspen on core elk winter range; or (3) try to maintain the existing aspen stands in the dry parks and valley bottoms on core elk winter range. The second goal permits aspen stands to fluctuate across the landscape, while the third goal takes a more static approach.

If the goal is simply to maintain some aspen in winter range, then the current natural regulation policy 


\section{A Senescent Stand}

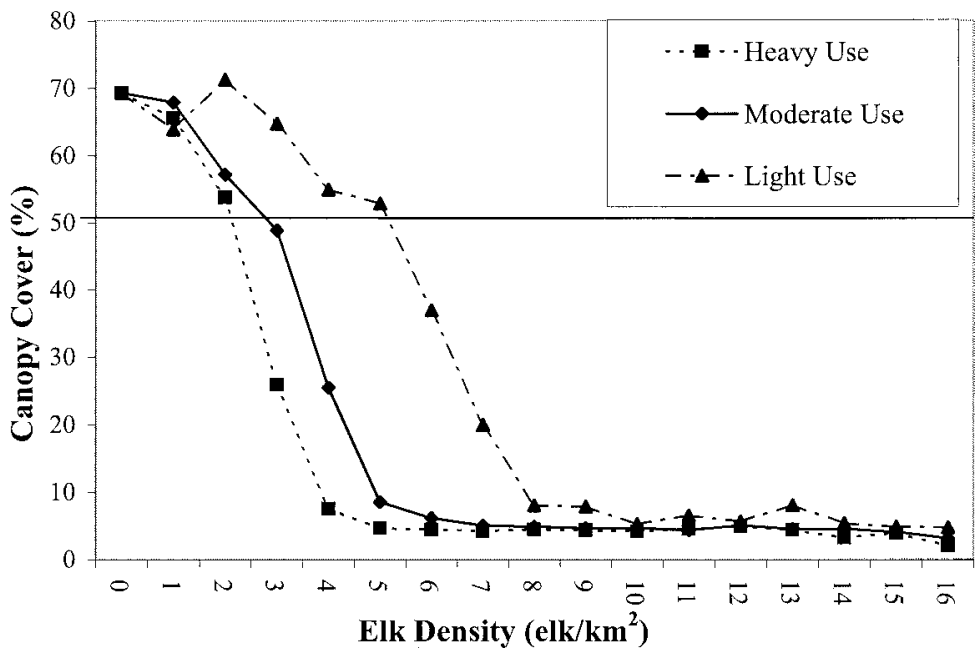

B Stand with a Younger Cohort

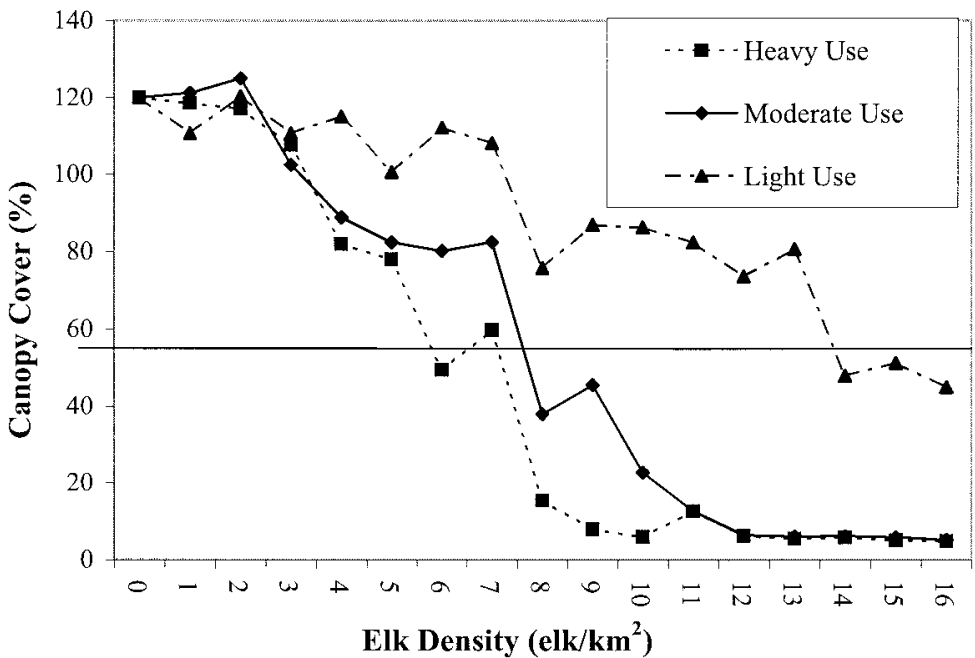

Figure 5. Aspen canopy cover (mean of 20 random simulation runs, after 60 years), reported for heavy, moderate, and light use treatments and for different levels of elk density: (a) for senescent aspen stands, and (b) for aspen stands with a younger cohort. The solid horizontal lines indicate the initial canopy cover of each treatment. for elk management would be satisfactory. It is unlikely that elk population levels would become high enough for aspen stands along the periphery of the winter range to experience high enough levels of elk herbivory to prevent successful aspen regeneration. At some point in the future, fires or silvicultural treatments might be required for these areas to maintain aspen. Aspen stands at the periphery of elk winter range are higher in elevation and tend to be successional to conifers.

Continuation of the current natural regulation policy is not likely to satisfy goals 2 and 3 without intensive management of aspen regeneration. Our simulation results suggest that aspen decline on core winter range areas in RMNP would be expected solely on the basis of elk population densities over the past several decades. These results are corroborated by empirical observations of successful aspen establishment and multicohort stands within exclosures and of widespread failure of aspen to regenerate outside exclosures (Olmsted 1977, Baker and others 1997). Natural regulation is not effective for allowing aspen regeneration on core winter range because aspen may be thought of as a "secondary prey" species, unable to exert a negative feedback on elk population levels because it constitutes only a small portion of the elk diet, but susceptible to impacts of high elk population levels supported by the availability of other winter forage sources. 
A Elk Distribution from Aerial Surveys (1994 - 1998)

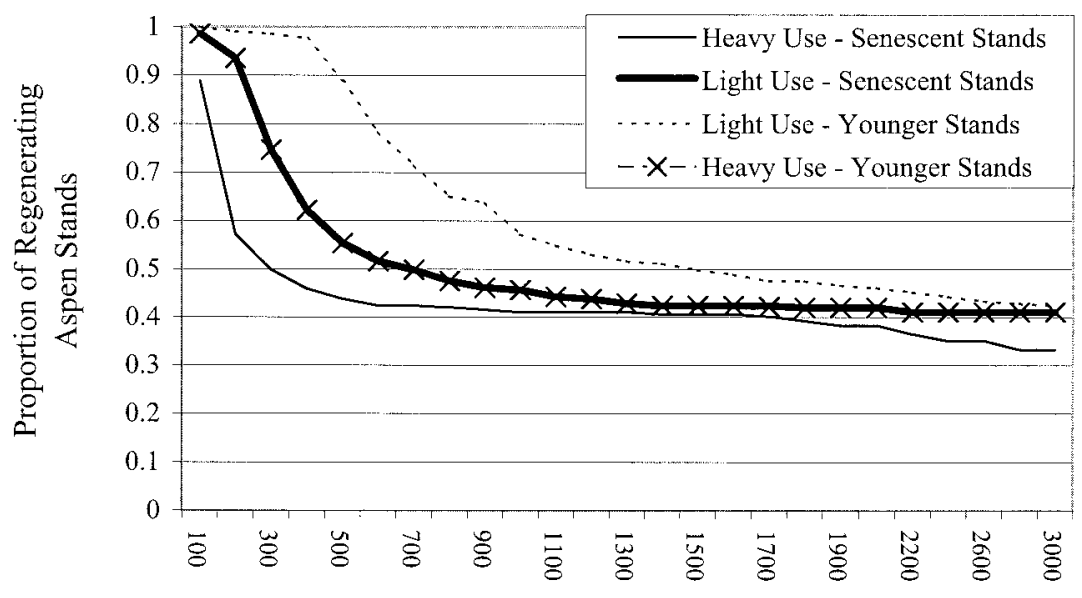

Elk Population Level

B Elk Distribution from SAVANNA Simulations (1960 - 1998)

Figure 6. The proportion of aspendominated area on elk winter range with successful aspen regeneration for at least $90 \%$ of random simulation runs, for different elk population levels ( $x$ axis), seasonal use intensities, and for senescent (solid curves) vs younger (dashed curves) aspen stands. (a) using elk distribution map based on interpolated aerial survey data (1994-1998), and (b) using SAVANNA simulations of winter (January-April) elk distribution (1960-1998).

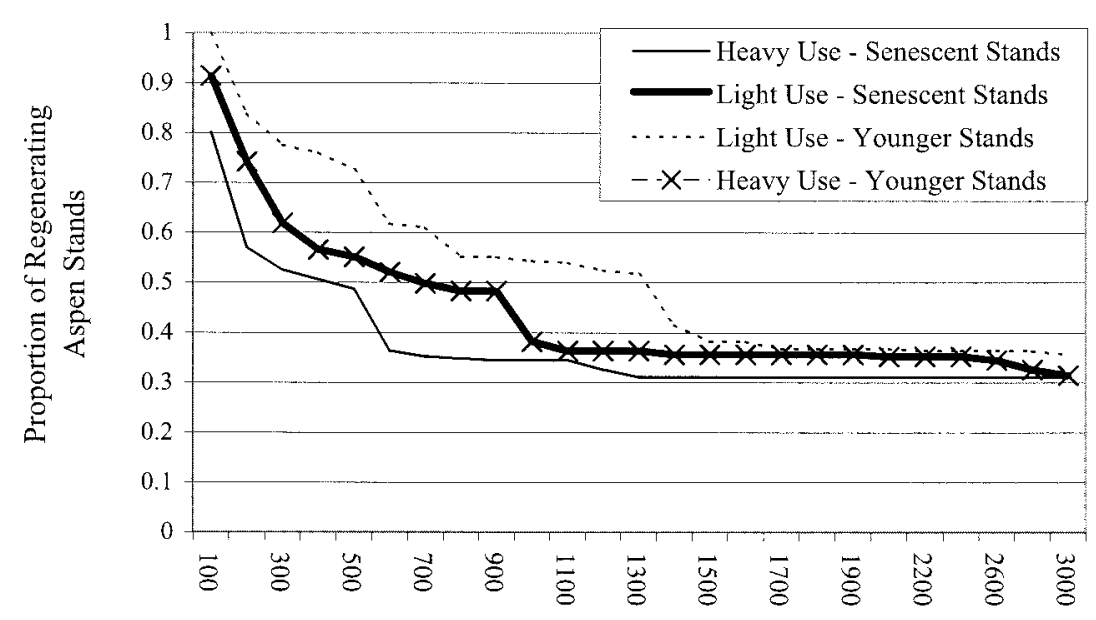

Elk Population Level
To maintain sufficient levels of aspen regeneration to ensure persistence of aspen in heavily utilized areas (e.g., Horseshoe Park, Beaver Meadows, and Moraine Park), while continuing the policy of natural regulation, it may be necessary to intensively manage for aspen regeneration by fencing aspen stands for long time periods (at least a 30-year period is suggested; Fig. 4c). However, aspen stands are likely to decline should fencing be followed by a long (e.g., 30-year) period without fences (Fig. 4c). In addition to fences, prescribed fire and mechanical disturbances (ripping, bulldozing) might be useful for stimulating abundant suckering (Shepperd 1996).

Discontinuing the policy of natural regulation in favor of a policy that reduces the size of the elk herd, may not be sufficient to create aspen persistence in the core of Estes Valley winter range. In a study of aspen population dynamics at RMNP, Baker and others (1997) found that aspen cohorts in the past have regenerated only when there were fewer than 600 elk on the winter range, or approximately one half of the current level. This is consistent with our simulation results for the heavy use scenario, where simulated elk distributions are used, and for the light use scenario, where empirical elk distributions are used (Fig. 6). For these scenarios of elk habitat use and distribution, aspen regeneration probability begins to increase with decreasing elk population level at levels below 500600. However, even at the 600-elk level, the probability of aspen regeneration may be quite low for many se- 

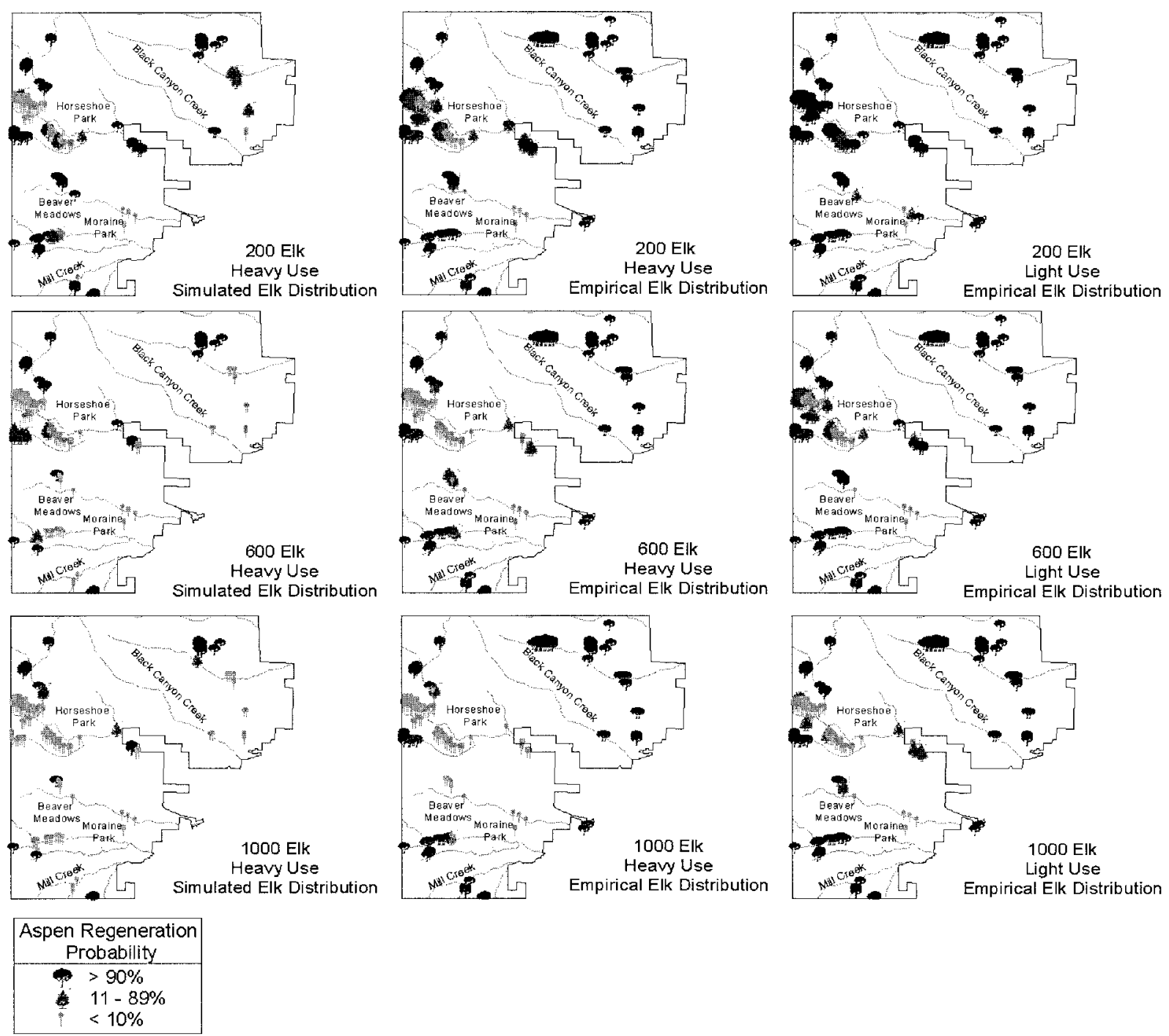

Figure 7. Predicted effects of three different elk population levels aspen regeneration success of senescent aspen stands, for heavy use (columns 1 and 2) and light use (column 3) scenarios. Results for the heavy use scenario are compared between GIS extrapolations using either simulated elk distribution maps (column 1) or empirical elk distribution maps (column 2) as inputs. The aspen regeneration probability, defined in the text, is calculated over 20 random weather scenarios where elk population is held constant.

nescent stands under all scenarios of elk use (Figures 6 and 7). Apparently, the 600-elk threshold identified in Baker and others (1997) represents a population level where aspen cohorts can initiate in certain places, but not in others where local elk densities reach higher levels.

Our results suggest that a population reduction to 100-300 elk may be necessary to allow regeneration of $90 \%$ of the park's senescent aspen stands. Less extreme reductions of the overall winter range elk population level may not be effective unless they are combined with management of local elk distribution for stimulating successful aspen establishment.
If aspen stands on core winter range were younger and more vigorous, formation of new age cohorts would be more likely to occur, for a given elk density (Fig 4b). The establishment of dense patches of young aspen also might present a physical barrier to elk herbivory, allowing additional aspen suckers to establish. Our results suggest that, while elk densities required for establishment of vigorous, multiaged aspen stands might be initially low, such aspen stands, once established, would be able to withstand greater elk densities.

Wolf reintroduction in RMNP might also facilitate aspen regeneration over much of the winter range. In Yellowstone National Park, where wolf reintroduction 
began in 1995, aspen suckers appear to be significantly taller in riparian areas heavily utilized by wolves than in areas of low wolf use (Ripple and others 2001). Prior to their extirpation, wolves may have limited the RMNP herd to fluctuations within a range of 300-800 elk (Coughenour 2001). However, several recent studies from Yellowstone National Park and the Canadian Rockies suggest that wolves may influence herbivoreplant interactions more through their behavioral effects, by altering elk spatial distributions, than through their numerical effects of reducing elk numbers (Ripple and Larsen 2000, Ripple and others 2001, White and others 2003). One might reasonably hypothesize that, if wolves were present, aspen on core winter range might be sustained at higher elk population levels than otherwise. This also implies that results from this modeling study for RMNP should not be directly extrapolated to other nature reserves where predators are present.

Successful management for aspen regeneration in the Estes Valley will likely require some combination of: overall elk population reduction, management of elk distribution, fencing to protect aspen suckers from elk browsing, mechanical disturbance or limited prescribed fire to stimulate suckering for stands with inherently low reproductive potential, and even chemical repellents to deter elk browsing at specific locations (Baker and others 1999). Since abundant aspen suckering has occurred in most existing exclosures, demonstrating the reproductive potential of these stands while an aspen overstory is still present, protection from elk browsing should play a far greater role in management plans than prescribed fire or mechanical disturbance.

Even with intensive management of elk distribution and elk access to aspen regeneration, it is unlikely that aspen could be maintained on Estes Valley core winter range locations without an overall reduction of the RMNP elk herd. This study suggests that, if preserving aspen stands on core winter range is a goal, RMNP management will need to reduce the overall elk herd size, while simultaneously conducting intensive, sitelevel activities to propagate aspen within the Estes Valley portion of the winter range.

While the recommended level of intervention (i.e., culling and fencing) may be controversial for a natural area such as RMNP, such measures may be necessary for maintaining aspen stands on core elk winter range. Whether these measures are consistent with RMNP's overall mandate to manage for a "natural system" is a complex, philosophical question that cannot be resolved using the methods of this study. It is arguable that, in the absence of large predators, human intervention may sometimes be necessary to maintain natu- ral vegetation patterns and processes where large ungulate herds are present.

\section{Acknowledgements}

We thank W. J. Ripple and two anonymous reviewers for providing helpful comments. W. Baker, T. Johnson, R. Monello, and F. Singer reviewed earlier versions of the manuscript. D. Barnett, G. Chong, M. Kaye, M. Khalkhan, R. Monello, C. Olmsted, M. Rock, W. Shepperd, F. Singer, T. Stohlgren and K. Suzuki provided critical data. This research was funded by Rocky Mountain National Park and EPA Project No. R827449-01-0.

\section{References}

Baker, D. L., W. F. Andelt, K. P. Burnham, and W. D. Shepperd. 1999. Effectiveness of Hot Sauce and Deer Away repellents for deterring elk browsing of aspen sprouts. Journal of Wildlife Management 63:1327-1336.

Baker, W. L., J. A. Munroe, and A. E. Hessl. 1997. The effects of elk on aspen in the winter range in Rocky Mountain National Park. Ecography 20:155-165.

Ball, J. T., I. E. Woodrow, and J. A. Berry. 1987. A model predicting stomatal conductance and its contribution to the control of photosynthesis under different environmental conditions. Pages 221-224 in I. Biggins (ed.), Progress in photosynthesis research. Martinees Nijhof, Dordrecht.

Barnett, D. T., and T. J. Stohlgren. 2001. Aspen persistence near the National Elk Refuge and Gros Ventre Valley elk feedgrounds of Wyoming, USA. Landscape Ecology $16: 569-580$.

Bartos, D. L., and R. B. Campbell, Jr. 1998. Decline of quaking aspen in the Interior West-examples from Utah. Rangelands 20:17-24.

Bartos, D. L., and R. S. Johnson. 1978. Biomass and nutrient content of quaking aspen at two sites in the western United States. Forest Science 24:273-280.

Bartos, D. L., and W. F. Mueggler. 1980. Influence of fire on vegetation production in the aspen ecosystem in western Wyoming. Pages 75-78 in M. S. Boyce, and L. D. HaydenWing (eds.), North American elk: ecology, behavior, and management. University of Wyoming Press, Laramie.

Beetle, A. A. 1974. Range survey in Teton County, Wyoming. Part 4-quaking aspen. Agricultural Experiment Station, Research Journal 31, Laramie, WY.

Boone, R. B., M. B. Coughenour, K. A. Galvin, and J. E. Ellis. 2002. Addressing management questions for Ngorongoro Conservation Area, Tanzania, using the Savanna modeling system. African Journal of Ecology 40:138-150.

Clarke, J. A., Olmsted, C. E., and Larkins K. 1994. Patterns of habitat use, movement, and distribution of elk adjacent to the eastern boundary of Rocky Mountain National Park. Summary report to Rocky Mountain National Park. Estes Park, Colorado.

Coughenour, M. B. 1992. Spatial modeling and landscape characterization of an African pastoral ecosystem: a proto- 
type model and its potential use for monitoring droughts. Pages 787-810 in D. H. McKenzie, D. E. Hyatt, and V. J. McDonald (eds.), Ecological indicators, Vol. I. Elsevier Applied Science, London.

Coughenour, M. B. 2001. Elk in the Rocky Mountain Park ecosystem-a model-based assessment. Final report to US. Geological Survey Biological Resources Division and US National Park Service, 132 pp.

Ellis, J. E., and M. B. Coughenour. 1998. The SAVANNA integrated modelling system: an integrated remote sensing, GIS and spatial simulation modelling approach. Pages 97106 in V. R. Squires, and A. E. Sidahmed (eds.), Drylands: sustainable use of rangelands into the twenty-first century. IFAD Series: Technical Reports.

Ellis, J. E., M. B. Coughenour, and D. M. Swift. 1993. Climate variability, ecosystem stability and the implications for range and livestock development. Pages 31-41 in R. Behnke, I. Scoones, and C. Kerven (eds.), Range ecology at disequilibrium. Overseas Development Institute, London.

Friend, A. D., H. H. Shugart, and S. W. Running. 1993. A physiology-based gap model of forest dynamics. Ecology 74:792-797.

Gruell, G. E., and Loope L. L. 1974. Relationships among aspen, fire, and ungulate browsing in Jackson Hole, Wyoming, U S Department of Agriculture, Forest Service, Intermountain Region.

Gysel, L. W. 1960. An ecological study of the winter range of elk and mule deer in the Rocky Mountain National Park. Journal of Forestry 58:696-703.

Hart, J. H., and D. L. Hart. 2001. Interaction among cervids, fungi, and aspen in northwest Wyoming. Pages 197-205 in W. D. Shepperd, D. Binkley, D. L. Bartos, T. J. Stohlgren, and L. G. Eskew (eds.), Sustaining aspen in western landscapes: symposium proceedings. USDA Forest Service Proceedings RMRS-P-18, Rocky Mountain Research Station, Fort Collins, Colorado.

Hess, K. 1993. Rocky times in Rocky Mountain National Park: an unnatural history. University Press of Colorado, Boulder.

Hinds, T. E. 1985. Diseases. Pages 87-106 in N. V. DeByle, and R. P. Winokur (eds.), Aspen: ecology and management in the western United States. Technical Report RM-119. USDA Forest Service General Rocky Mountain Forest and Range Experiment Station, Fort Collins, Colorado.

Hobbs, N. T. 1996. Modification of ecosystems by ungulates. Journal of Wildlife Management 60:695-713.

Hobbs, N. T., D. L. Baker, J. E. Ellis, and D. M. Swift. 1981. Composition and quality of elk winter diets in Colorado. Journal of Wildlife Management 45:156-171.

Jones, J. R., and G. A. Schier. 1985. Growth. Pages 19-24 in N. V. DeByle, and R. P. Winokur (eds.), Aspen: ecology and management in the western United States. General Technical Report RM-119. USDA Forest Service Rocky Mountain Forest and Range Experiment Station, Fort Collins, Colorado.

Kay, C. E. 1993. Aspen seedlings in recently burned areas of Grand Teton and Yellowstone National Parks. Northwest Science 67:94-104.

Kay, C. E. 1997a. Is aspen doomed? Journal of Forestry 95:4-11.
Kay, C. E. 1997b. Viewpoint: ungulate herbivory, willows, and political ecology in Yellowstone. Journal of Range Management 50:139-145.

Larkins, K. F. 1997. Patrterns of elk movement and distribution in and adjacent to the eastern boundary of Rocky Mountain National Park. MS thesis. University of Northern Colorado, Greeley, Colorado.

Milchunas, D. G., W. K. Lauenroth, P. L. Chapman, and M. K. Kazempour. 1989. Effects of grazing, topography, and precipitation on the structure of a semiarid grassland. Vegetatio 80:11-23.

Mueggler, W. F. 1989. Age distribution and reproduction of intermountain aspen stands. Western Journal of Applied Forestry 4:41-45.

National Park Service. 1988. Management policies. US Department of the Interior, Washington, DC.

Olmsted, C. E. 1977. The effect of large herbivores on aspen in Rocky Mountain National Park. PhD thesis. University of colorado, Boulder, Colorado.

Olmsted, C. E. 1997. Tweny years of change in Rocky Mountain National Park elk winter range aspen. Unpublished report to Rocky Mountain National Park. Estes Park, Colorado.

Peinetti, R. 2000. Riparian willow dynamics and their interaction with environmental and biological factors in the elk winter range of Rocky Mountain National Park (Colorado) - a multi-scale analysis. PhD thesis. Colorado State University, Fort Collins, Colorado.

Ripple, W. J., and E. J. Larsen. 2000. Historic aspen recruitment, elk, and wolves in northern Yellowstone National Park, USA. Biological Conservation 95:361-370.

Ripple, W. J., E. J. Larsen, R. A. Renkin, and D. W. Smith. 2001. Trophic cascades among wolves, elk and aspen on Yellowstone National Park's northern range. Biological Conservation 102:227-234.

Romme, W. H., M. G. Turner, L. L. Wallace, and J. S. Walker. 1995. Aspen, elk, and fire in Northern Yellowstone National Park. Ecology 76:2097-2106, PhD thesis. Colorado State University, Fort Collins, Colorado.

Romme, W. H., M. G. Turner, R. H. Gardner, W. W. Hargrove, G. A. Tuskan, D. G. Despain, and R. A. Renkin. 1997. A rare episode of sexual reproduction in aspen (Populus tremuloides Michx.) following the 1988 Yellowstone fires. $>$ Natural Areas Journal 17:17-25.

Ruark, G.A. 1985. Biomass, net primary production, and nutrient distribution in successionary Populus tremuloides Michx. stands on an entic haplorthod in nort-central Wisconsin. PhD thesis. University of Wisconsin, Madison.

Schier, G. A. 1975. Deterioration of aspen clones in the middle Rocky Mountains. Research Paper INT-170. USDA Forest Service, Intermountain Forest and Range Experiment Station, Ogden, Utah.

Shepperd, W. D. 1990. A classification of quaking aspen (ASPENCLS) in the Central Rocky Mountains based on growth and stand characteristics. Western Journal of Applied Forestry 5:69-75.

Shepperd, W. D. 1993. Initial growth, development, and clonal dynamics of regenerated aspen in the Rocky Moun- 
tains. Research Paper RM-312. USDA Forest Service, Rocky Mountain Forest and Range Experiment Station, Fort Collins, Colorado.

Shepperd, W. D. 1996. Response of aspen root suckers to regeneration methods and post-harvest protection. Research Paper RM-RP-324. USDA Forest Service, Rocky Mountain Forest and Range Experiment Station, Fort Collins, Colorado.

Singer, F. J., L. C. Mark, and R. C. Cate. 1994. Ungulate herbivory of willows on Yellowstone's northern winter range. Journal of Range Management 47:435-443.

Singer, F., Elliott, T., Coughenour, M., Welker, J., Valentine, D., Williams, S., Zeigenfuss, L., Alstad, K., Menezes, R., Peinetti, R., Barnett, D., Cates, R., and Zou, J. 1998. Large mammalian herbivores, plant interactions, and ecosystem processes in five national parks. Third Annual Report on Cooperative Agreement 1445-0009-94-1074, Subagreement 2, to Midcontinent Ecological Science Center, Biological Resources Division of US Geological Survey, Fort Collins, Collins.

Spalinger, D. E., and N. T. Hobbs. 1992. Mechanisms of foraging in mammalian herbivores: new models of functional response. American Naturalist 140:325-348.

Stevens, D. R. 1979. Effect of elk on vegetation in Rocky Mountain National Park. Unpublished report to Rocky Mountain National Park.
Stohlgren, T. J., G. W. Chong, M. A. Kalkhan, and L. D. Schell. 1997. Multiscale sampling of plant diversity: effects on minimum mapping unit size. Ecological Applications 7:1064-1074.

Suzuki, K., H. Suzuki, D. Binkley, and T. J. Stohlgren. 1999. Aspen regeneration in the Colorado Front Range: differences at local and landscape scales. Landscape Ecology 14:231-237.

Wang, J. R., A. L. Zhong, P. Comeau, M. Tsze, and J. P. Kimmins. 1995. Aboveground biomass and nutrient accumulation in an age sequence of aspen. (Populus tremuloides) stands in the Boreal White and Black Spruce Zone, British Columbia. Forest Ecology and Management 78:127-138.

Weisberg, P. J., N. T. Hobbs, J. E. Ellis, and M. B. Coughenour. 2002. An ecosystem approach to population management of ungulates. Journal of Environmental Management 65:181-197.

White, C. A., C. E. Olmsted, and C. E. Kay. 1998. Aspen, elk and fire in the Rocky Mountain national parks of North America. Wildlife Society Bulletin 26:449-462.

White, C. A., M. C. Feller, and S. Bayley. 2003. Predation risk and the functional response of elk-aspen herbivory. Forest Ecology and Management (in press).

Wolff, J. O. 1978. Burning and browsing effects on willow growth in interior Alaska. Journal of Wildlife Management 42:135-140. 